\title{
Application of Synergisticity Model in High-Tech Industrial Cluster Innovation System

\author{
Min Chen ${ }^{1,2, ~ a, ~ Q i u m i n g ~ W u ~}{ }^{1, b}$ \\ ${ }^{1}$ School of Economics and Management, Fuzhou University, Fuzhou City, 350108, China \\ ${ }^{2}$ Department of Mathematics, FuJian University of Technology, Fuzhou City, 350118, China \\ a fjlssh@126.com, ${ }^{b}$ qiuming30@sina.com
}

Keywords: coordinating degree; industrial cluster; order degree.

Abstract. Based on synergetics, through to the research of high-tech industry cluster innovation system, Having established the coordination model of industrial cluster innovation system. Carrying on the empirical analysis by practical examples and verifying the correctness of the model.

\section{Introduction}

From 1987, China's first national high-tech Zone---ZhongGuanCun was born. High-tech Zone has become an important driving force to promote the development of national economy in China, which plays an extremely important role, in improving the industrial structure, activing regional economy. And independent innovation ability is the key factor of regional economy, which has the international competitive advantage and competitiveness, but also the fundamental driving force of regional economic development. Therefore, it is of great theoretical and practical significance to study the innovation capability of high-tech industrial clusters in the development of regional economy. The innovation capability of high-tech industry cluster is: in the New District, based on a development period, to enhance the economic growth of high-tech zone as the goal, make full use of enterprise, University, research institutions, financial institutions, intermediary service agencies and government and other enterprises to improve the efficiency of the main body of innovation, efficient allocation of innovation re-sources, the new product and service ability to transform into a comprehensive analysis and evaluation . This study based on the theory of CO students, combined with the characteristics of high-tech industry cluster innovation system, set up a coordination degree evaluation model of high-tech industrial cluster innovation system, hoping to have some help to the innovation of high-tech industrial clusters.

\section{Research methods}

Collaborative theory of coordination degree from the German physicist Herman Hawking proposed in 1971. The degree of harmony in the process of development and evolution of the system or between the system components is called coordination degree. Haken think system transformation and not by the system control parameters (order parameter) decision system in the critical region of internal variables of the synergy system from disorderly to orderly degree and trend. The key to the system to order is the interaction between the subsystems in the system. The coordination degree is the measurement of the synergy, and the co scheduling model is a quantitative model for the degree of coordination of the system.

\subsection{Power function}

Hypothesis, the evaluation index of innovation system of high-tech industry cluster (S) is $u_{i}(i=1,2,3 \ldots, n)$, its value is $x_{i}(i=1,2,3 \ldots, n), \alpha_{i}, \beta_{i}$ is the upper and lower limit of the stability of the system and represents the target value and the minimum value of the evaluation index. The value of order parameter $x_{i}$ can be positive or negative, and the value of the system is higher, the order of the 
system is higher, and the value of the system is smaller. In addition, the value of $x_{i}$ may also be a positive and negative change. This is because with the development of the system, the effect of the order parameters on the system development and the evolution of the system will also change. Thus, the order parameter $x_{i}$ can be defined as the function of the order parameter $S^{[4-5]}$ for the order of the system:

$$
W_{A}\left(u_{i}\right)= \begin{cases}\frac{x_{i}-\alpha_{i}}{\beta_{i}-\alpha_{i}}, & \text { When } W_{A}\left(u_{i}\right) \text { has a positive effect } \\ \frac{\alpha_{i}-x_{i}}{\alpha_{i}-\beta_{i}}, & \text { When } W_{A}\left(u_{i}\right) \text { has a negative effect } \\ \frac{x_{0}-\left|x_{i}-x_{0}\right|}{x_{0}}, i \in[1, m] & \text { when } x_{i}<x_{0}, W_{A}\left(u_{i}\right) \text { has a positive effect } \\ \text { when } x_{i} \geq x_{0}, W_{A}\left(u_{i}\right) \text { has a positive effect }\end{cases}
$$

In the formula, $W_{A}\left(u_{i}\right)$ is an indicator of the contribution of $u_{i}$ to the degree of order of the system; $\mathrm{A}$ is the stable region of the system; $x_{0}$ is the reasonable value of order parameter.

\subsection{Coordination function}

By the formula (1) we can know, the greater of its value, the contribution of A to the corresponding system is greater. Order parameter variable total contribution to the order of the system can be reacted by the coordination function. There are usually have two methods of calculation, one is the arithmetic average, the other is the geometric average. The geometric mean method is used here.

$$
C=C\left(u_{i}\right)=\sqrt[n]{W_{A}\left(u_{1}\right) W_{A}\left(u_{2}\right) \ldots W_{A}\left(u_{n}\right)}=\sqrt[n]{\prod_{i=1}^{n} W_{A}\left(u_{i}\right)}
$$

Coordination of $\mathrm{C}$ reflects the coordination of innovation system of high-tech Industrial clusters, $\mathrm{C}$ is between $0 \sim 1$, $\mathrm{C}$ value is higher, the overall coordination of high-tech industrial clusters innovation system is better, the higher the comprehensive benefit. The key to this model is the selection of the upper and lower limits of the function, and the determination of its value can be determined according to the actual situation of the regional high-tech industrial clusters.

\section{Index system construction of innovation system of high tech industry cluster}

This research is based on the research results of domestic and foreign, and analyzes the main factors that affect industrial cluster technological innovation capability. According to the basic principles of systematic, operational, effective, comparability, dynamic continuity and so on, the paper establishes the order parameter of industrial cluster innovation system to four kinds, namely, technological innovation investment capability, technological innovation capability, technological innovation diffusion ability and technical innovation support capability. Each parameter is subdivided into a number of sub variables, corresponding to the statistical index . 
Table 1 comprehensive evaluation index system of innovation system of high tech Industrial Cluster

\begin{tabular}{|c|c|c|c|}
\hline $\begin{array}{c}\text { Evaluation } \\
\text { object }\end{array}$ & $\begin{array}{l}\text { Sub system } \\
\text { classification }\end{array}$ & Order parameter index & Efficacy \\
\hline \multirow{9}{*}{ 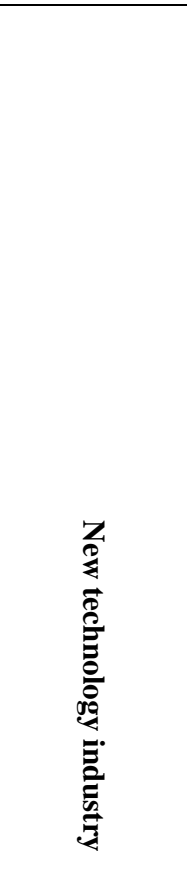 } & \multirow{4}{*}{$\begin{array}{l}\text { Technical innovation } \\
\text { input ability index }\end{array}$} & Investment in science and Technology $\left(X_{1}\right)$ & + \\
\hline & & R\& D Fund investment $\left(X_{2}\right)$ & + \\
\hline & & $\begin{array}{l}\text { Number of scientists and engineers in scientific and } \\
\text { technological activities }\left(X_{3}\right)\end{array}$ & + \\
\hline & & Research and development organization number $\left(X_{4}\right)$ & + \\
\hline & \multirow{5}{*}{$\begin{array}{l}\text { Technical innovation } \\
\text { output capability index }\end{array}$} & Patent licensing quantity $\left(X_{5}\right)$ & + \\
\hline & & System science and technology papers published volume $\left(X_{6}\right)$ & + \\
\hline & & New products and new process output value $\left(X_{7}\right)$ & + \\
\hline & & $\begin{array}{l}\text { Contribution of scientific and technological progress } \\
\text { to the growth of GDP }\left(x_{8}\right)\end{array}$ & + \\
\hline & & $\begin{array}{l}\text { Number of awards for scientific and technological } \\
\qquad \text { innovation }\left(X_{9}\right)\end{array}$ & + \\
\hline \multirow{9}{*}{ 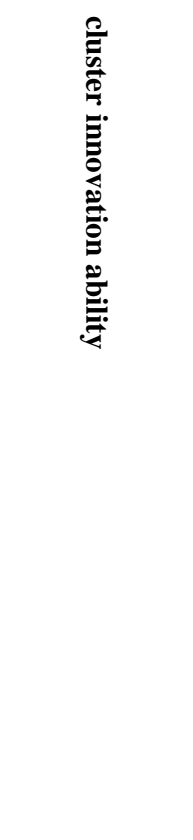 } & \multirow{3}{*}{$\begin{array}{l}\text { Technology innovation } \\
\text { diffusion ability index }\end{array}$} & Technical market contract transaction volume $\left(X_{10}\right)$ & + \\
\hline & & Technology introduction of digestion and absorption $\left(X_{11}\right)$ & \pm \\
\hline & & Conversion of industrial technology achievements $\left(X_{12}\right)$ & \pm \\
\hline & \multirow{6}{*}{$\begin{array}{l}\text { Technical innovation } \\
\text { support capability index }\end{array}$} & Government support for innovation policy $\left(X_{13}\right)$ & \pm \\
\hline & & $\begin{array}{l}\text { Productivity Promotion Center and technology } \\
\text { promotion center number }\left(X_{14}\right)\end{array}$ & + \\
\hline & & Number of financial institutions $\left(X_{15}\right)$ & + \\
\hline & & Bank loans for technology development ( $\left.X_{16}\right)$ & + \\
\hline & & Number of colleges and universities $\left(X_{17}\right)$ & + \\
\hline & & Library number $\left(X_{18}\right)$ & + \\
\hline
\end{tabular}

Note: the effect of the positive and negative is that the order parameter of the system in order to produce positive and negative effect, or is close to the reasonable value direction of positive effect.

\section{Empirical analysis}

In this study, the Fuzhou high-tech Zone as an example of empirical research. In the model, the effect of the "+" or "-" of the lower limit value of the index of the various order parameters are mainly based on the historical data of Fuzhou high-tech Zone, data using the lowest value of the data from 2010 to 2014; and the upper bound of the relevant data in the other high-tech Zone of the city. Taking into account the size and structure of the similarity, We mainly choose the same period of Xiamen hi-tech Zone and Fuzhou hi-tech Zone. A higher value of the two regions is used as the upper limit value. And the effectiveness of the model is the "+" of the various order parameter index reasonable value is 
the National High-tech Development Zone in the same period of the data to determine the mean value. In addition, the actual data as the index of order parameters of the majority of the 2009-2014 from the "China Torch Statistical Yearbook", "China's high tech Industry Yearbook", "China Statistical Yearbook" and "Fuzhou statistical yearbook". The coordination degree of the innovation capability of the high-tech Zone of Fuzhou city can be calculated by the above function and coordination function (Table 2).

Table 2 evaluation results of the coordination degree of the innovation system of Fuzhou hi tech Industrial Cluster in 2010-2014

\begin{tabular}{|c|c|c|c|c|c|c|}
\hline \multirow{2}{*}{$\begin{array}{l}\text { Evalua } \\
\text {-tion } \\
\text { object }\end{array}$} & \multirow{2}{*}{$\begin{array}{l}\text { Sub system } \\
\text { classifycat-ion }\end{array}$} & \multirow{2}{*}{$\begin{array}{l}\text { Sub system } \\
\text { order } \\
\text { parameter } \\
\text { type }\end{array}$} & \multicolumn{3}{|c|}{$\begin{array}{c}\text { System order degree of order parameter of sub } \\
\text { system }\end{array}$} & \multirow{2}{*}{$\begin{array}{c}\text { Subsystem } \\
\text { coordinatio } \\
\text { n degree }\end{array}$} \\
\hline & & & $\begin{array}{l}2011 \\
\text { (year) }\end{array}$ & $\begin{array}{l}2012 \\
\text { (year) }\end{array}$ & $\begin{array}{l}2013 \\
\text { (year) }\end{array}$ & \\
\hline \multirow{18}{*}{ 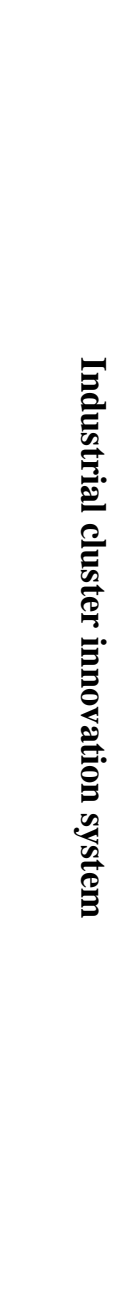 } & \multirow{4}{*}{$\begin{array}{l}\text { Technology } \\
\text { innovation input } \\
\text { ability subsystem }\end{array}$} & $X_{1}$ & 0.271 & 0.219 & 0.416 & 0.396 \\
\hline & & $x_{2}$ & 0.163 & 0.183 & 0.295 & 0.306 \\
\hline & & $x_{3}$ & 0.599 & 0.605 & 0.657 & 0.699 \\
\hline & & $x_{4}$ & 0.067 & 0.117 & 0.201 & 0.200 \\
\hline & \multirow{5}{*}{$\begin{array}{l}\text { Technology } \\
\text { innovation output } \\
\text { ability subsystem }\end{array}$} & $x_{5}$ & 0.456 & 0.675 & 0.667 & 0.673 \\
\hline & & $x_{6}$ & 0.687 & 0.422 & 0.489 & 0.613 \\
\hline & & $x_{7}$ & 0.252 & 0.533 & 0.818 & 0.576 \\
\hline & & $x_{8}$ & 0.262 & 0.426 & 0.711 & 0.531 \\
\hline & & $x_{9}$ & 0.214 & 0.238 & 0.262 & 0.340 \\
\hline & \multirow{3}{*}{$\begin{array}{l}\text { Technology } \\
\text { innovation diffusion } \\
\text { ability subsystem }\end{array}$} & $x_{10}$ & 0.249 & 0.404 & 0.665 & 0.508 \\
\hline & & $x_{11}$ & 0.201 & 0.896 & 0.556 & 0.562 \\
\hline & & $x_{12}$ & 0.146 & 0.243 & 0.468 & 0.359 \\
\hline & \multirow{6}{*}{$\begin{array}{l}\text { Technology } \\
\text { innovation support } \\
\text { system }\end{array}$} & $x_{13}$ & 0.356 & 0.533 & 0.633 & 0.589 \\
\hline & & $x_{14}$ & 0.594 & 0.733 & 0.788 & 0.765 \\
\hline & & $x_{15}$ & 0.256 & 0.422 & 0.567 & 0.497 \\
\hline & & $x_{16}$ & 0.231 & 0.289 & 0.45 & 0.417 \\
\hline & & $x_{17}$ & 0.368 & 0.426 & 0.484 & 0.525 \\
\hline & & $x_{18}$ & 0.424 & 0.644 & 0.802 & 0.684 \\
\hline
\end{tabular}

From the results of the evaluation, in the system of technical innovation input ability, the coordination degree is the highest in the number of scientists and engineers, the coordination of other order parameters is less than 0.5. It shows that the industrial cluster of Fuzhou hi-tech Zone is not enough, the number of $\mathrm{R} \& \mathrm{D}$ institutions is relatively small, so the space of innovation investment and development is still increasing. In the system of technological innovation output ability, the coordination degree of the order parameter is less than 0.5, it shows that the Fuzhou high tech Zone has the insufficiency in the science and technology innovation, which has affected the whole innovation level. In the technology innovation diffusion ability subsystem, the coordination value of the industrial technology achievement conversion application rate is less than 0.4, it shows that the high tech Zone has defects in the transformation of industrial production, and the practical application of innovation results in the future should be strengthened. In 
the supporting system of technological innovation, the order parameter of the system is increasing year by year, this shows that the government's support for the innovation process in Fuzhou hightech Zone is also increasing year by year.

\section{Conclusion and Prospect}

In this paper, the coordination degree evaluation model of the innovation system of high-tech industrial cluster is established based on the theory of synergetic theory and order parameter, and the evaluation of the industrial cluster system of Fuzhou high-tech industrial cluster is carried out. The evaluation results reflect the present situation of Fuzhou hi tech industrial cluster innovation ability, and explain the high reliability and operability of the comprehensive evaluation of innovation ability of high tech Industrial Clusters by using coordination degree model. In addition, using the model to evaluate the innovation capability, not only can evaluate the coordination degree of the innovation system and the sub system, but also can find the specific target and the type of the system, which can help the decision makers to develop a targeted policy and measure.

\section{Acknowledgements}

This work was financially supported by the 2014 Fujian Provincial Department of education funded projects "industrial clusters collaborative innovation mechanism re-search" (project number JAS14211) and 2014 National Natural Science Foundation of China, "scientific and technological innovation platform cluster formation mechanism and Research on Mechanism of synergy" (item number 71350014).

\section{References}

[1] Fan Bainai, in:"Research on the evaluation of the technological innovation capability of the national hi tech Zone”, edited by Science Research, vol.21, (2003) ,p. 667.

[2] Haken H: Synergetics (Springer, Berlin 1978).

[3] Guan Hua and Ma Jianhua, in: "System science and its application in geography”, (Science Press, Beijing 2003 ).

[4] Li Zhibin, in: "Study on the evaluation index system and method of regional sustainable development”, edited by Human geography, (1998),p.70.

[5] Ou Xiong, Shen Qingyun and Feng Changchun, in: "Application of coordination degree model in the evaluation of urban land use potential”, edited by Geography and Geographic Information Science, (2007), p. 618.

[6] Jiang Xiaoran, Liu Zhongwen and Zhang Xuping, in: "Evaluation index system and model construction of regional technological innovation capability in China”, edited by Technology economy and management, (2009) pp. 32.

[7] Liu Zhongwen, Zhang Xuping and Zhang Feng, in: "Research on the evaluation and evaluation of regional technological innovation capability”, edited by Economic Research Guide, (2010), p. 137. 